Volume 37, n. 1 - p. 61-74, jan./mar. 2019 - Florianópolis

Augusto Cesar Rios Leiro Universidade Federal da Bahia, UFBA

E-mail: cesarleirocbce@gmail.com

(D) http://orcid.org/0000-0002-6075-5187

Ednaldo da Silva Pereira Filho Universidade do Vale do Rio dos Sinos, Unisinos

E-mail: ednaldo@unisinos.br

http://orcid.org/0000-0001-7996-2939

Paulo Cesar de Carvalho Lima Universidade Federal da Bahia, UFBA E-mail: falecompaulolima@gmail.com

(i) http://orcid.org/0000-0002-2024-5166

Recebido em: 07/11/2017

Aprovado em: 03/10/2018

\section{Fotografias em Instagram: imagens de práticas corporais e sociabilidades em parques públicos citadinos de lazer}

\section{Augusto Cesar Rios Leiro Ednaldo da Silva Pereira Filho Paulo Cesar de Carvalho Lima}

\section{Resumo}

O objetivo do artigo é identificar e refletir acerca das sociabilidades humanas por meio da análise de imagens de práticas corporais em parques públicos citadinos de lazer fotografadas e veiculadas no Instagram. É um estudo exploratório de natureza quanti-qualitativa sobre imagens capturadas no Instagram e tomadas aqui como moldura, através do sistema de busca e rastreamento da geolocalização de dois parques públicos de cidades metropolitanas brasileiras, as quais foram importadas para o MAXQDA com o intuito de facilitar a categorização e a elucidação das informações qualitativas. Como primeiras sínteses, as sociabilidades se expressam de forma singular na internet, ao lado de imagens espetacularizadas da vida cotidiana dos sujeitos, que no instante em que fazem suas postagens estão produzindo relações sociais mediadas por imagens, portanto estreitando seus círculos sociais. Dessa forma, o espaço real e o espaço virtual não se constituem como ambientes distintos quando o assunto é a sociabilidade humana.

Palavras-chave: Fotografia. Práticas Corporais. Sociabilidades. 


\begin{abstract}
Photographs in Instagram: images of corporate practices and sociabilities in public parks leisure citadines

The objective of this article is to identify and reflect on human sociabilities by analyzing images - photographed and transmitted in the Instagram - of corporal practices in public urban leisure parks. It is an exploratory study of quantitativequalitative nature of images captured in Instagram and taken here as a frame, through the system of search and tracking of the geolocation of two public parks of Brazilian metropolitan cities and that were imported to MAXQDA in order to facilitate the categorization and elucidation of qualitative information. As a first

Keywords:

Photography. Body

Practices.

Sociabilities. synthesis, sociabilities express themselves singularly on the internet alongside spectacular images of daily life of subjects, who at the instant they make their posts are producing social relations mediated by images, thus narrowing their social circles. In this way, real space and virtual space do not constitute distinct environments when it comes to human sociability.
\end{abstract}

\section{Resumen}

Palabras clave:

Fotografía. Prácticas

Corporales.

Sociabilidades.
Fotografias en Instagram: imagen de práticas corporativas y sociabilidades em parques públicos citadinos de lazer

El objetivo del artículo es identificar y reflexionar acerca de las sociabilidades humanas por el análisis de imágenes - fotografiadas y transmitidas en el Instagram - de prácticas corporales en parques públicos urbanos de ocio. Es un estudio exploratorio de naturaleza cuantitativa y cualitativa de imágenes capturadas en Instagram y tomadas aquí como marco através del sistema de búsqueda y rastreo de la geolocalización de dos parques públicos de ciudades metropolitanas brasileñas y que fueron importadas al MAXQDA con el fin de facilitar la integración categorización y elucidación de las informaciones cualitativas. Como primeras síntesis las sociabilidades se expresan de forma singular en Internet al lado de imágenes espectaculares de la vida cotidiana de los sujetos, que en el instante que hacen sus posturas están produciendo relaciones sociales mediadas por imágenes, por lo tanto estrechando sus círculos sociales. De esta forma, el espacio real y el espacio virtual no se constituyen como ambientes distintos cuando el asunto es la sociabilidad humana. 


\section{Introdução}

"Espetacularizar o eu consiste precisamente nisto: transformar nossas personalidades e vidas privadas em realidades ficcionalizadas com recursos midiáticos."

Sibilia (2008)

A efervescência do mundo contemporâneo, ao lado dos incríveis avanços das Tecnologias da Informação e Comunicação (TIC), transformou os nexos entre a realidade e a virtualidade de sociabilidades presentes nas práticas corporais da vida cotidiana nos diferentes espaços urbanos ao redor do mundo. Trata-se, portanto, de um fenômeno marcado por distintas formas de pensar, conhecer, aprender e agir, bem como pela capacidade de resolver problemas cada vez mais complexos, que, por sua vez, necessitam não apenas de concepções racionalizadas, mas sobretudo de subjetividades e sensibilidades de distintas aprendizagens.

A expansão das formas de comunicação e expressão, principalmente via internet, possibilita a existência de uma grande coletividade produtiva, que considera as dimensões geográficas, geracionais, étnicas, religiosas, entre outras, mas ultrapassa tais perspectivas. Essa amplificação demanda cada vez mais a conexão entre múltiplas áreas de conhecimento que desafiam uma falsa dicotomia entre realidades reais e virtuais.

Nesse cenário, as imagens ganham evidência, em particular a fotografia. No entanto as instituições, em sua maioria, demonstram uma visão instrumental dessa técnica e pouco apreendem das suas formas de comunicar, expressar, socializar e entender o momento atual. Sendo assim, lançamos mão da fotografia como possibilidade de captação de texto imagético e inspiração de texto escrito, a fim de compreender sociabilidades a partir de leituras de fotografias de práticas corporais em parques públicos de lazer que são veiculadas em rede social, no caso, o Instagram. Nessa perspectiva, entendemos a fotografia como linguagem e dispositivo automático que vem sendo apropriada por parte significativa da população.

No presente texto, temos o intuito de identificar e descrever sociabilidades através da análise de imagens de práticas corporais em parques públicos de lazer fotografadas e veiculadas no Instagram. Para tal, tomamos como pontos de partida os estudos de Debord (1997) sobre a inundação de imagens no cenário contemporâneo; de Sibilia (2008), com sua reflexão acerca da intimidade como espetáculo, a partir da discussão intitulada "show do eu"; de Lazzarotti Filho e colaboradores (2010), na sua caracterização sobre as práticas corporais como fenômeno cultural; de Simmel (1983), com a noção de sociabilidade; de Joly (2007), no trato do conhecimento analítico relativo às imagens; e de Leiro (2001), no tocante aos parques públicos de lazer como tecidos urbanos das cidades e espaços-tempos de encontros de sujeitos. 


\section{Fotografia como máquina de produção de imagens}

O look do dia, o que foi servido na última refeição, os momentos com a família, uma selfie, as práticas corporais, enfim, tudo ou um simulacro de tudo vem sendo representado por imagens e imediatamente compartilhado entre o círculo de amigos e seguidores em rede telemática. Os artefatos tecnológicos e a propagação da vida comum através de fotografias em redes sociais evidenciam “[...] que a imagem é realmente uma linguagem, uma linguagem específica e heterogênea; que a este título se distingue do mundo real e que propõe, por meio de signos particulares, uma representação escolhida e forçosamente orientada [...]" (JOLY, 2007, p. 53).

Isso nos permite refletir sobre à clássica alegoria da Caverna, de Platão (2002), onde ver e conhecer as coisas se limitava às representações das imagens das sombras projetadas na parede. Essa obra filosófica inaugura o debate dicotômico sobre o conhecimento racional das ideias e o das coisas sensíveis, considerado pelo filósofo como um conhecimento de senso comum e vulnerável às nossas percepções e sensibilidades. Com as realidades virtuais, estamos vivendo um rico momento para reproblematizar com a fotografia este debate epistemológico e social.

Nessa perspectiva, para a fotografia de hoje, a história começou no final do século XIX, quando Louis Jacques Mandé Daguerre registrou, em 1838, um homem que engraxava os sapatos na rua Boulevard du Temple, em Paris. Nessa fotografia, o ser humano aparece desfocado, pois o tempo de exposição ${ }^{1}$ necessário à tecnologia da época para capturar as imagens era muito longo, o que não garantia a nitidez dos assuntos que se movimentavam nas cenas fotografadas. Outra característica dessa imagem é o distanciamento territorial entre o fotógrafo e o fotografado, ou seja, o mesmo aparato tecnológico não propiciava determinados tipos de enquadramentos e tomadas de ângulo, como os autorretratos, popularmente conhecido como selfies, hoje tão comuns. A relação do sujeito com seu retrato era necessariamente mediada por alguém, que manuseava o equipamento fotográfico, o que o tornava, o tempo todo, uma visão de si a partir do olhar do outro.

Para transmutação do cenário entre o sujeito, sua selfie e as cenas do seu cotidiano, além de outros fatores, ressaltamos a chegada da fotografia digital, a fabricação dos smartphones e o advento das redes sociais. Entre estes fatores, o primeiro que focalizamos é a associação da captura de imagens digitais com os smartphones, que, “[...] mediante uma incitação permanente à criatividade pessoal, à excentricidade e à procura constante da diferença, não cessa de produzir cópias e mais cópias descartáveis do mesmo" (SIBILIA, 2008, p. 9). É evidente que esse excesso de produção gera um tempo, em que se destaca a imagem, produzindo de modo singular a espetacularização da realidade, categoricamente pontuada por Debord (1997), na relação entre as condições de produção das sociedades modernas, a representação do que é vivido diretamente e a constituição de relações sociais medidas por imagens. 
É nesse contexto que o Instagram é tomado como moldura. O Instagram é uma rede social on-line de compartilhamento de fotos e vídeos lançada em outubro de 2010. Antes do seu lançamento, a primeira fotografia publicada nessa rede data de 10 julho do mesmo ano e encontra-se disponível no perfil @kevin, que pertence a Kevin Systrom, um dos criadores do Instagram:

Figura 1 - Captura de tela do perfil de @kevin, no Instagram

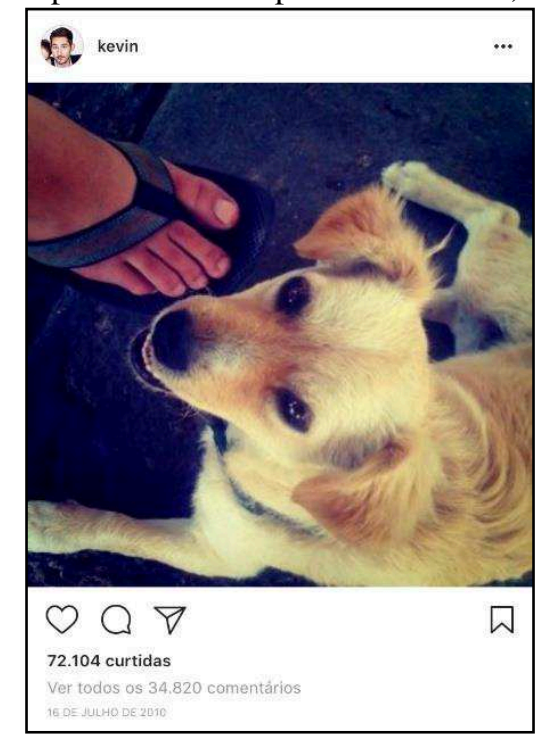

Fonte: Perfil de @kevin no Instagram,16 de julho de 2010.

A tomada da foto, do alto, cortando um pé calçado numa sandália de dedo, ao lado de partes de um filhote de cachorro da raça Golden Retriever, tem a marcação na postagem de @ nicole, que parece ser a namorada de @kevin, e registrava,no dia 26 de setembro de 2017, 72.104 curtidas acompanhadas de 34.820 comentários dos mais diversos tipos e de vários locais do mundo. Essa captura traz indícios do estabelecimento de uma estética fotográfica informal, que se relaciona de modo íntimo com o cotidiano do sujeito que dispõe do artefato tecnológico. Essa estética, ora revelada, ganha força à medida que exibe cenas clichês do dia a dia na rede, consolidando-se entre seus pares através do número considerável de curtidas e comentários. Com essa perspectiva, aprofundaremos a compreensão sobre a sociabilidade e seus nexos entre a realidade e a virtualidade.

\section{Sociabilidade real e virtual em práticas corporais}

É muito comum nos depararmos com a falsa dicotomia cartesiana entre o real e o virtual e, para tornar compreensível nosso posicionamento de não polarização, recorremos a Simmel (1983), que diz não existir sociedade no sentido abstrato; o que temos são pessoas que agem e reagem entre si e

[...] a importância destas interações está no fato de obrigar os indivíduos, que possuem aqueles instintos, interesses, etc. a formarem uma unidade - precisamente uma 'sociedade' e ainda afirma [...] tudo que está presente neles de maneira a engendrar ou mediar influências sobre outros (SIMMEL, 1983, p. 166). 
E, nesse sentido, o autor alerta que os interesses, as preocupações e as motivações não são em si mesmas sociais, pois dependem das diferentes interações - sejam elas aqui chamadas de virtuais ou reais - dos indivíduos uns com os outros, contra os outros e pelos outros. Nessa perspectiva, sublinha que tanto o ambiente "real” quanto o "virtual” estão sujeitos a essa necessidade de oportunizar interações e, por conseguinte, considerar os interesses, as preocupações e as motivações como dimensões constituintes da base das sociedades humanas, inclusive a contemporânea, com todos estes traços e rabiscos tecnológicos.

É nessa perspectiva que as postagens no Instagram aumentam de maneira significativa a sociabilidade entre o indivíduo que tem o equipamento em mãos e os seus pares, bem como a aproximação da produção fotográfica ao cotidiano dos sujeitos. É o que afirmam Castells e Cardoso (2005) quando reconhecem na sociabilidade digital uma grande possibilidade das pessoas se associarem às outras, fazendo referências a estudos em diferentes sociedades que apontam os usuários de internet como pessoas mais conectadas e sociáveis.

As imagens de práticas corporais em parques públicos de lazer nos oportunizam exercitar o conceito de sociabilidade, ${ }^{2}$ pois se distinguem de outras formas de interações sociais a partir do momento que têm um fim em si mesmas e são capazes de despertar fascínio e excitação nos envolvidos. Aliás, fascínio e excitação são competências humanas típicas das fotografias emolduradas pelo Instagram.

Em se tratando de sociabilidade, o que mais vai contar são o sucesso e a lembrança do momento sociável, no qual, principalmente, as pessoas se encontram num convívio social marcado pela amabilidade, cordialidade, satisfação, alegria e outras fruições. Nada de maiores compromissos ou seriedades. Aliás, quando os limiares da sociabilidade ${ }^{3}$ são desconsiderados, a experiência vivenciada passa a ser uma mera formalidade.

$\mathrm{Na}$ esteira desse debate, as práticas corporais se inscrevem no presente texto como categoria analítica que busca evitar os reducionismos que estamos acostumados a adotar e naturalizar como verdades. No intuito de ampliar as nossas lentes, levamos em conta a diversidade de sentidos e significados que as pessoas atribuem às suas distintas culturas de movimento: esporte, ginástica, luta, dança, jogo, entre outras. Com isso, estamos demarcando que ninguém precisa ficar refém da lógica funcionalista, que reduz historicamente os propósitos das pessoas que fazem atividade física, como se elas estivessem exclusivamente preocupadas em ficar magras ou em melhorar o seu condicionamento físico. Elas até podem adotar premissas como essas, mas estão livres para assumir outros objetivos e motivações.

Assim, optamos por ampliar nossos olhares, para perceber outros sentidos que fazem as pessoas irem para os parques públicos de lazer e emoldurarem suas práticas corporais no Instagram.

É exatamente nessa perspectiva que Lazarrotti Filho e colaboradores (2010) irão salientar que as práticas corporais de movimento podem ser representadas com caracteres mais tradicionais de adestramento, precisão, sistematização, competição e outros, mas também são passíveis de serem 
ressignificadas nas práticas diárias, do cotidiano, da simplicidade e enriquecidas tanto pelas culturas ocidentais quanto pelas orientais.

\section{Trilhas metodológicas: para além do que se mostra}

O campo empírico fez sentido à medida que envolveu práticas corporais, produção de imagens e parques públicos citadinos de lazer, mediado pelo ato de fotografar. A presente reflexão considerou: o cenário, o sujeito e a comunicação pública uma tríade qualificada para melhor compreender os nexos da relação sujeito-objeto e reafirmar a face figurativa e a face simbólica presentes nos diferentes flagrantes da corporalidade. No debate em torno dos flagrantes aqui propostos, destacam-se gestos, sorrisos e um inventário de práticas corporais de movimento.

Para tanto, navegamos no Instagram e, através do sistema de busca por localização disponibilizado no aplicativo, rastreamos os pontos de geolocalização de dois parques públicos: Parque Metropolitano de Pituaçu e Parque Marinha do Brasil. O parque é reconhecido aqui como um lugar social plural, que congrega num único território sujeitos de gênero, identidade étnico-racial e gerações distintas. Para Leiro (2001, p. 27), trata-se de um "retrato urbano" de crescente e variado interesse cultural, "polivalente, recortado por zonas livres e de aparelhos" que reúne características "ambientais, infraestruturais e funcionais".

A primeira busca trouxe um volume de mais de 2 mil fotografias, o que exigiu uma redução do campo amostral de investigação. Assim, restringimos o período do recorte entre os dias 22 e 30 de julho de 2017, em plena vigência das férias escolares das redes públicas municipais de ensino de Salvador-BA, onde fica o Parque Metropolitano de Pituaçú, e de Porto Alegre-RS, local do Parque Marinha do Brasil. Esse recorte nos trouxe um número menor de fotografias, que passamos a capturar toda vez que se revelava uma representação de prática corporal. Capturamos 83 fotografias de perfis distintos no Instagram, dentre as quais 47 foram retiradas da geolocalização Parque Marinha do Brasil e 36 do Parque Metropolitano. Em alguns casos, consideramos outros argumentos, como as curtidas, os comentários e as hashtags ${ }^{4}$ com o intuito de compreender as doxas e facilitar a interpretação e a reinterpretação das informações quanti-qualitativas. Para tanto, importa sublinhar que o marco conceitual da internet em foco aqui elege três faces para o trabalho investigativo, qual sejam:

[...] pode ser tanto objeto de pesquisa (aquilo que se estuda), quanto local de pesquisa (ambiente onde a pesquisa é realizada) e, ainda, instrumento de pesquisa (por exemplo, ferramenta para coleta de dados sobre um dado tema ou assunto). (FRAGOSO; RECUERO; AMARAL, 2011, p. $17)$.

Nesse sentido, as noções de internet estão fundamentalmente relacionadas como objeto, local e procedimento de pesquisa, estabelecendo, de forma interdisciplinar, relações com as pistas sobre análise de imagens, que, segundo Joly $(2007$, p. 51), “[...] pode, entretanto, preencher funções diferentes e tão 
variadas como proporcionar prazer ao analista, aumentar os seus conhecimentos, instruir, permitir a leitura ou conceber mais eficazmente mensagens visuais", as reflexões de sociabilidades, segundo Simmel (1983), e o conceito de práticas corporais sintetizado por Lazarroti Filho e colaboradores. (2010).

É um estudo exploratório de natureza quanti-qualitativa, que, segundo Creswell (2007) caracteriza-se pela análise de dados numéricos e estatísticos coletados juntamente com dados imagéticos, formando assim um método misto. Para Santos (2009), uma pesquisa de método misto possibilita uma maior compreensão dos fenômenos sociais, devido aos múltiplos aspectos expostos na coleta de dados. Dessa forma, após a redefinição do filtro de imagens, importamo-las para o MAXQDA ${ }^{5}$, com o intuito de facilitar a categorização e elucidação das informações qualitativas. As fotografias foram codificadas a fim de quem pudéssemos entender como os sujeitos ocupam os espaços públicos, como as culturas corporais expressam-se nos ambientes públicos de lazer, a circulação social como pontos dinâmicos de encontro de sujeitos, como ocorrem as manifestações intergeracional e o locus como palco de registro dos acontecimentos. Assim, a tematização, sistematização e descrição de frequência das informações levantadas nos indicaram como categorias substantivas: a) relações de gênero, b) círculos sociais, c) gerações dos sujeitos, d) locais dos acontecimentos e e) práticas corporais.

As fotografias reunidas foram dispostas e categorizadas levando em consideração as cenas capturadas, os cenários recortados dos parques e as curtidas de sujeitos previamente escolhidos e posteriormente organizadas em gráficos. Também foram marcadas pela tensão conceitual entre o aparente e o essencial, no tocante a perceber a autenticidade das informações e seus eventuais contrastes, bem como entender os nexos entre os sujeitos e realidade complexa, multidimensional e polilógica em que vivemos. Assim, buscamos entender, aprofundar e refletir acerca das possibilidades do mundo virtual e dos modos de comunicação do movimentar-se no parque como recorte da vida urbana. No entanto é do mundo vivido corporalmente ou do mundo visto ou sentido que emerge basicamente a presença do ser em si, e da forma de percepção sobre as práticas corporais de movimento, notadamente, o esporte.

O desafio foi capturar, na peleja entre a recorrência e o estranho, o estável e o instável, o individual e o coletivo, o que as inúmeras poses foram revelando como fazer, e textos imagéticos dos jeitos de corpos. Tais clivagens, no entanto, foram sementes essenciais para entender as imagens em movimento e sua insistência de visibilidade, através de fecundo debate envolvendo o cotidiano como esteira para análise das trocas e comunicações quase tangíveis. Foram clicks estáticos com palavras suplementares que se entrecruzaram através de uma palavra, de um gesto, de uma caminhada e de um beijo, no jogo do mundo cotidiano, nos quais as fotos congelam instantes e impregnam nosso olhar de mediações.

Nesse mosaico de textos escritos e imagéticos, destacamos as implicações nas narrativas e fotografias recolhidas em duas fases: "uma fase analítica, na qual há um desmembramento das unidades 
de significantes e uma fase de organização, sintética, construtiva” (PAIS, 2001, p. 103). Nessa perspectiva, a técnica de bricolagem se inscreve como uma possibilidade, na medida em que a

[...] atitude e prática de desmontagem e montagem, unindo e relacionando conteúdos fragmentados, como as palavras o fazem quando falam de uma vida [...] esse é o desafio da análise interpretativa, o de trabalhar os fragmentos de sentido, interconectando-os, revirando-lhes os sentidos. (PAIS, 2001, p. 103).

Iniciando a análise com a categoria "relações de gêneros", de acordo com o Gráfico 1, percebe-se uma presença substancial das mulheres, mesmo que a exposição dos homens e de atividades mistas sejam - quantitativamente - maiores, pois em se tratando de espaços públicos de lazer, com toda essa publicidade da mídia de que "a rua é lugar perigoso", é muito relevante que tanto homens quanto mulheres insistam em desconstruir essa premissa. A presença feminina nestes espaços da cidade afirma também, na ambiência do lazer, a ocupação diversa de homens e mulheres na cena pública.

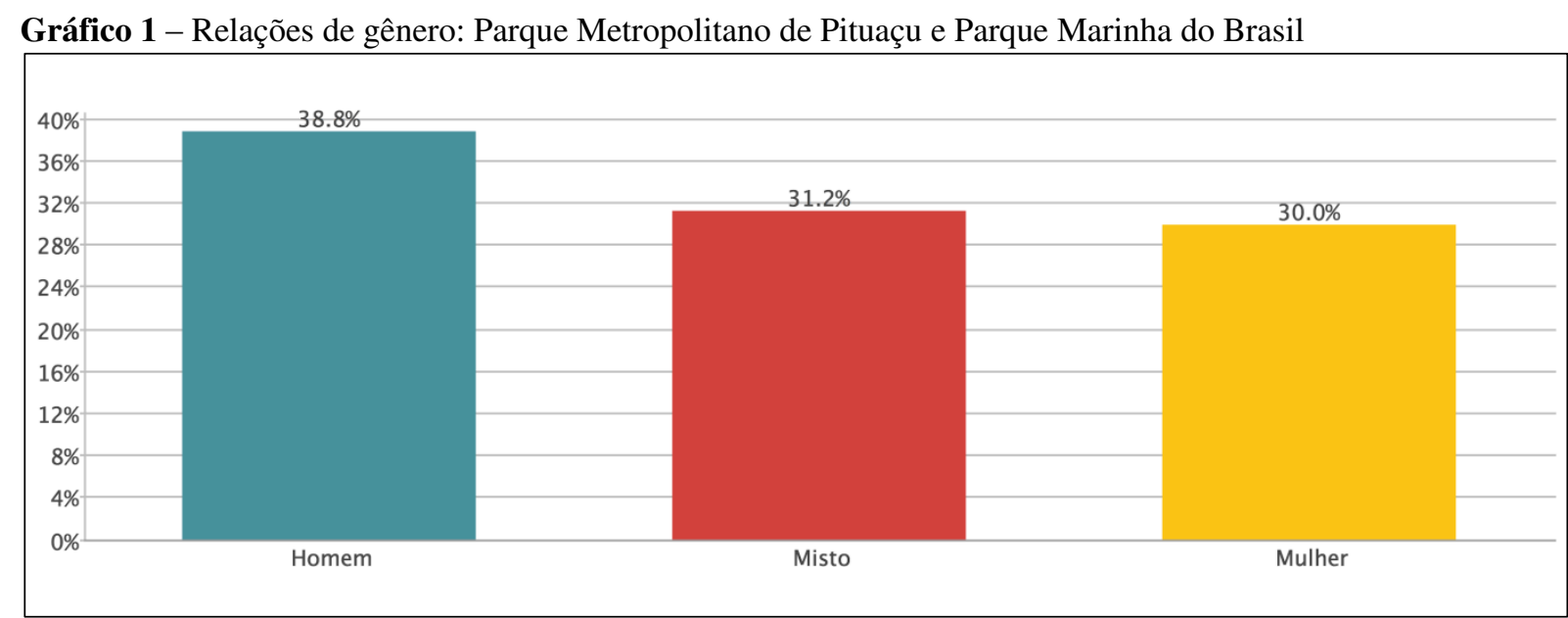

Fonte: elaborado pelos autores através do MAXQDA.

Da mesma forma, percebe-se abaixo, no Gráfico 2, uma certa diversidade de "círculos sociais", apesar de um pequeno realce na representação da realização de práticas corporais coletivas $(52,4 \%)$, que são constituídas pelo somatório dos estratos: a) com amigos; b) com família; c) namorados (heterossexuais e homoafetivos) e vêm logo acompanhadas das representações individuais (36\%), público em geral $(7,5 \%)$ e paisagens $(3,8 \%)$. Salienta-se que essa representação nos parques públicos é tanto individual como coletiva e, dessa forma, as interações sociais resultantes das práticas corporais são emolduradas no Instagram em poses que denotam a vitória frente a algum desafio, geralmente acompanhadas de textos ou de hashtags motivacionais ou alusivas a grandes feitos, como a diminuição do tempo de realização de um determinado percurso de bicicleta ou de corrida. E assim, conforme propala Debord (1997), independentemente de estarem fisicamente sozinhas ou acompanhadas, as pessoas, no instante em que fazem suas postagens, estão produzindo relações sociais mediadas por imagens, portanto estreitando seus círculos sociais. 
Gráfico 2 - Círculos sociais: Parque Metropolitano Pituaçu e Parque Marinha do Brasil

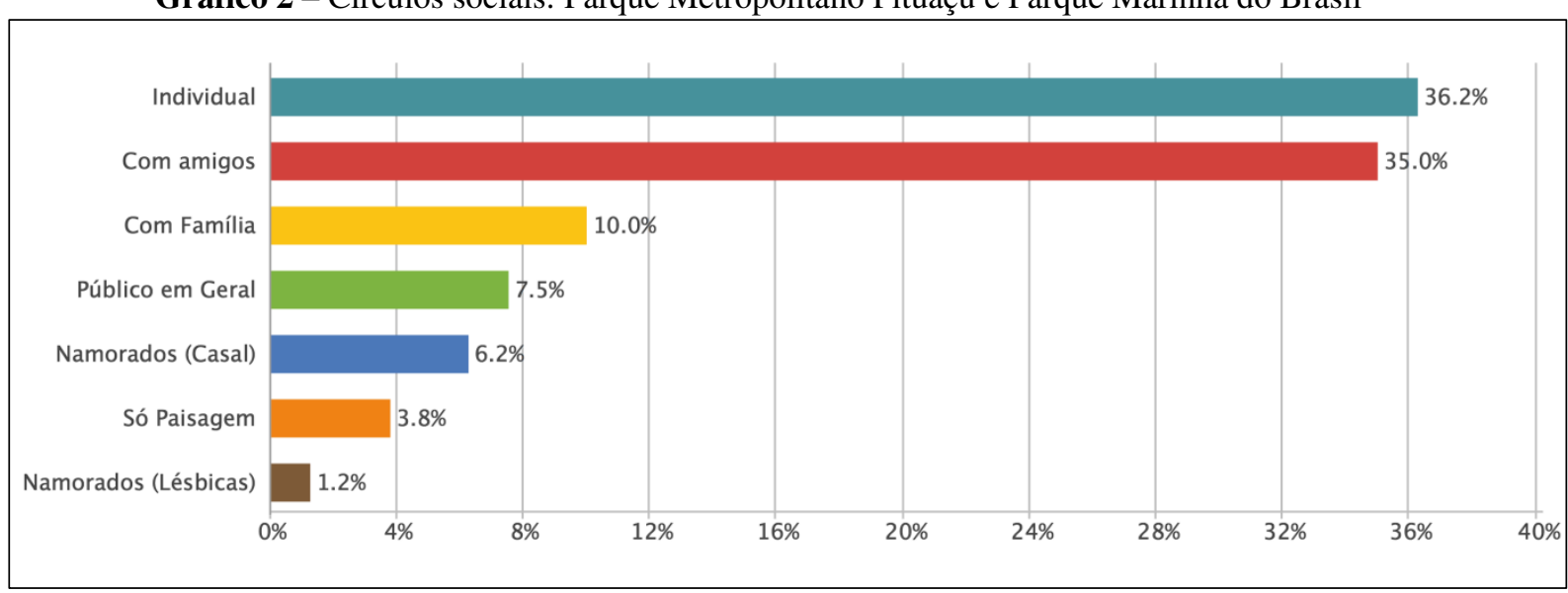

Fonte: elaborado pelos autores através do MAXQDA.

O prefixo "ana", de "analisar", remete, etimologicamente, à ideia de sentidos contrários, de novos sentidos. Sentidos que possam rebelar-se contra os ligamentos de vida que nos são dados numa aparente linearidade, em sua forma lisa (PAIS, 2001, p. 103). Examinando-se o Gráfico 3, nota-se uma predominância culturalmente típica da geração de jovens $(43,8 \%)$, pela tradicional familiaridade desse grupo com as novas tecnologias, mas, curiosamente, seguida por um grupo intergeracional (27,5\%), que ao mesmo tempo - refuta a naturalização da rivalidade entre gerações e mostra, em registros imagéticos, novas possibilidades de convivência pública e harmoniosa entre pessoas com idades diferentes que desfrutam de perspectivas semelhantes por também difundirem suas experiências com as práticas corporais em parques públicos.

Gráfico 3 - Gerações: Parque Metropolitano Pituaçu e Parque Marinha do Brasil

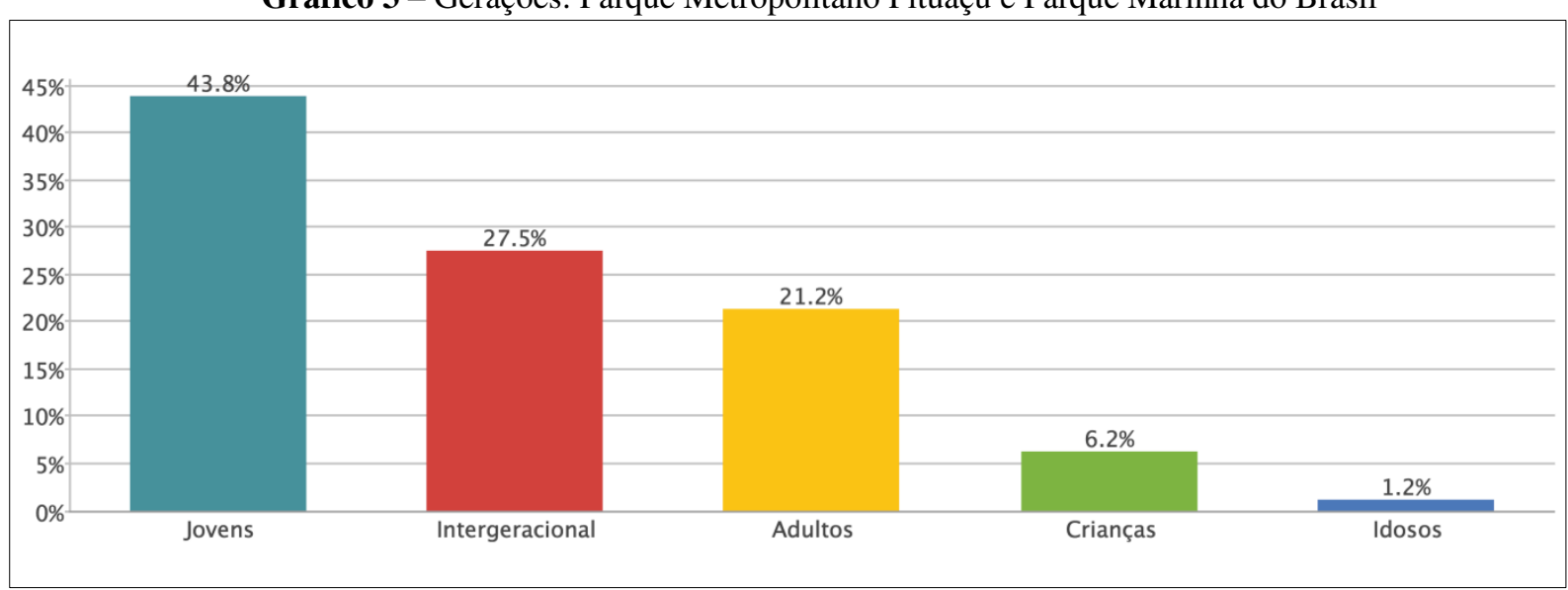

Fonte: elaborado pelos autores através do MAXQDA.

Por fim, mesmo com indicadores menores, a geração dos idosos $(1,2 \%)$ - ainda aquém às crianças e aos adultos - deixa seu registro de sociabilidade no Instagram como forma simbólica de avisarem que estão chegando também ao habitat virtual e anunciam um novíssimo "Frevo Novo" (música de Caetano Veloso), pois, se “a Praça Castro Alves é do povo como o céu é do avião”, os espaços virtuais não o são. 
Gráfico 4 - Cenários: Parque Metropolitano Pituaçu e Parque Marinha do Brasil

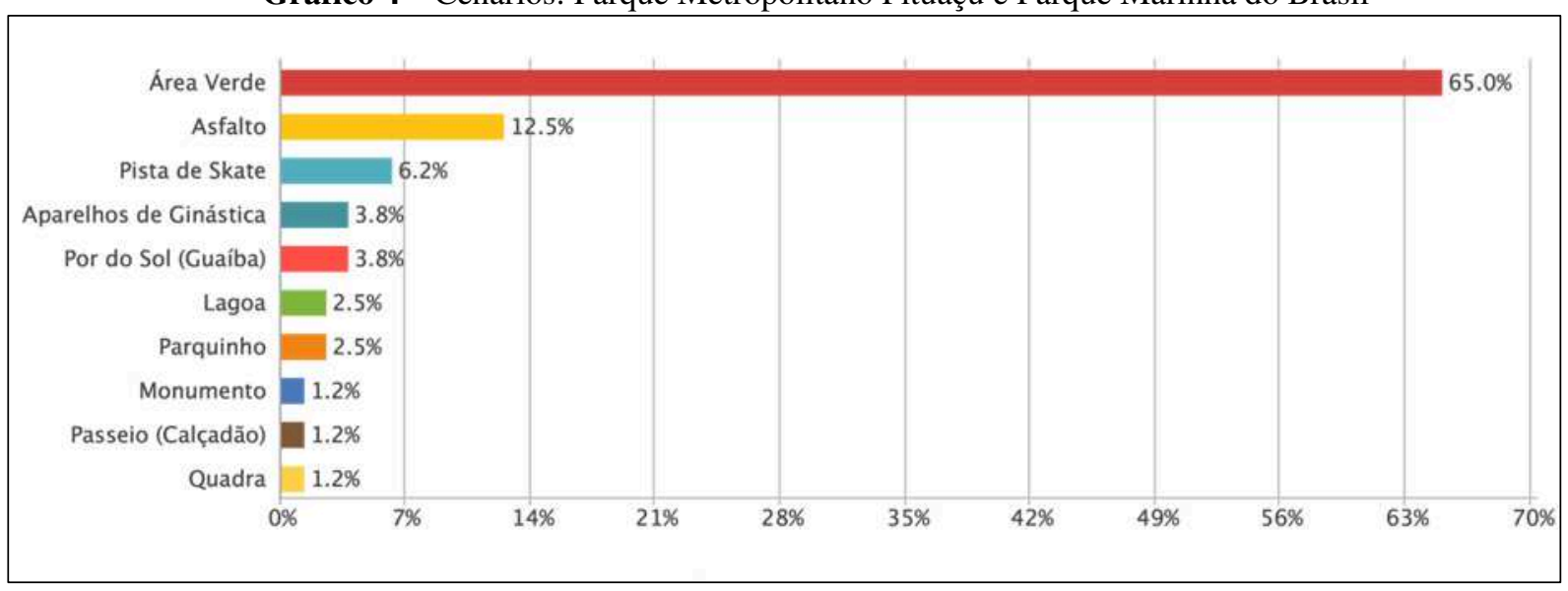

Fonte: elaborado pelos autores através do MAXQDA.

No Gráfico 4, observamos a movimentação dos sujeitos nos "locais" para compor o cenário das fotos. É importante contextualizar que essas duas cidades fazem parte dos estudos de uma rede nacional de pesquisa do Observatório das Metrópoles, na qual Fedozzi, Soares e Mamarella (2015, p. 26) destacam a importância de reconceptualizar a noção de espaço social, pois, para além de se caracterizar como “distribuição dos objetos, dos equipamentos, da urbanidade, das relações e dinâmicas espaciais, em centralidade e periferia”, sobretudo por ser traduzido nas “[...] conexões postuladas entre ordem subjetiva interna (atitudes, tradições e aspirações) e a ordem espacial externa dentro de um meio urbano [...]”, é preciso que a ele se incorporem as peculiaridades da tecnologia que modificam essas conexões entre os lugares e potencializam os fluxos de sociabilidades.

Gráfico 5 - Práticas Corporais: parque Metropolitano Pituaçu e Parque Marinha do Brasil

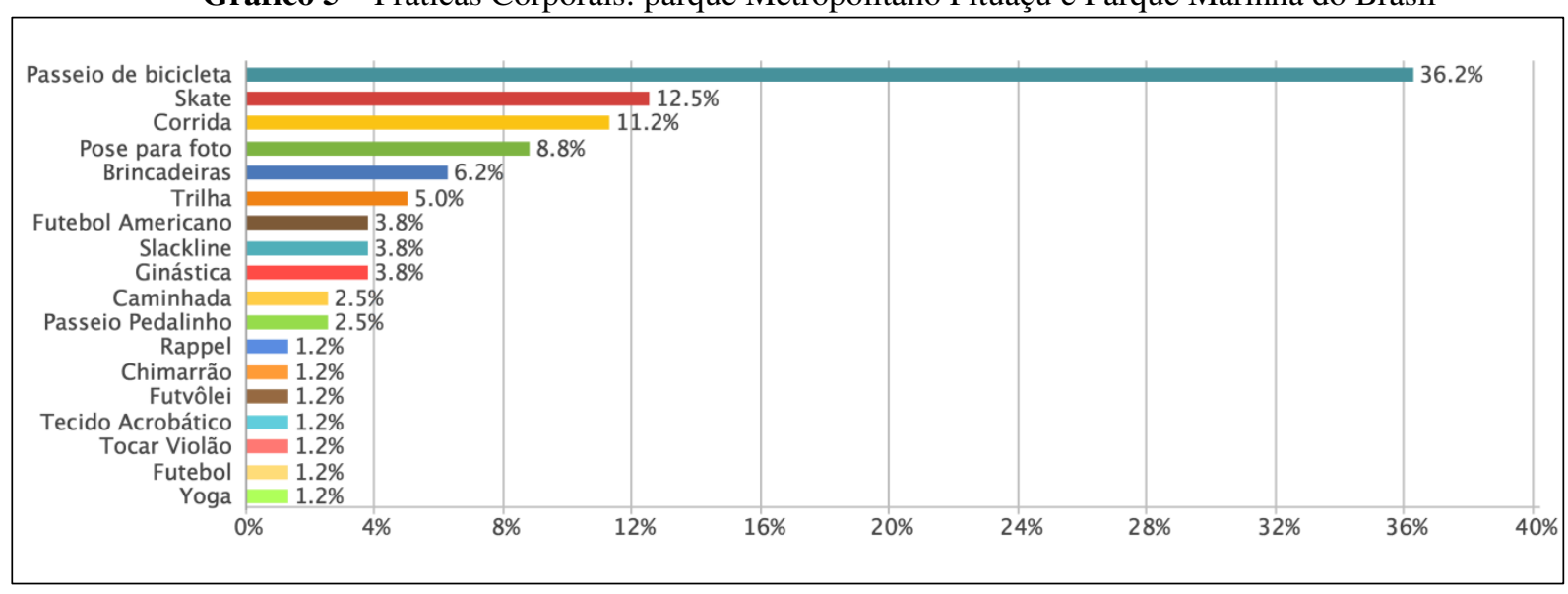

Fonte: elaborado pelos autores através do MAXQDA.

Nesse sentido, de acordo com o Gráfico 5, os parques estudados apresentaram uma outra possibilidade de diversidade de manifestações de práticas corporais que transcende a referida hegemonia do esporte, tão divulgado e espetacularizado nas mídias.

Aqui temos uma predominância de práticas com o uso da bicicleta, para além do esporte performance, mais afetas ao lúdico, descomprometidas, um suave e interativo passeio de bicicleta. Nesse 
mesmo sentido, vemos o skate, a corrida de rua, as simples brincadeiras ou os sofisticados slackline, futebol americano, trilhas e tantas outras práticas corporais de movimento que são vivenciadas com intensidades, regularidades e intencionalidades plurais. A sensação é de que as pessoas nos parques observados reinventam e ousam na cotidianidade - conforme Lazarrotti Filho e colaboradores (2010) -, ao vivenciarem as práticas corporais de movimento de diferentes formas e em sintonia com as diversidades culturais.

\section{Sínteses para instigar}

A aventura da escrita e análise de imagens pautadas por metodologias que tomam a internet como dimensão e objeto de estudo nos conduziu para uma quantidade significativa de considerações sobre as imagens de práticas corporais de movimento capturadas no Parque Metropolitano de Pituaçú e no Parque Marinha do Brasil que foram veiculadas na rede social Instagram. Foram sínteses possíveis, (in)conclusivas e instigantes, dentre as quais destacamos como provocações: a promoção do ordinário como (e)vento e sua visibilidade ao circular na rede; o recorte e o ângulo do autorretrato e seu deslocar-se do plano fotográfico para o intento do compartir com legendas escrachadas e criativas que apresentam um simples ato como um feito sensacional. Na moldura, não é mais o treino de corrida, tornou-se o excelente treino de corrida; a equipe de prática de exercícios físicos deixou de ser alegre, transmutando-se para a mais animada; o passeio em caminhos já abertos na mata virou trilha extrema; os momentos particulares são gatilhos para conselhos de como viver melhor a partir de frases de impactos de grandes pensadores que se descontextualizam ao lado de expressões melancólicas ou de extrema alegria. De fato, os acontecimentos comuns ganham notoriedade, mas são esquecidos no minuto seguinte, pois as poses, expressões, estilos de legendas e conteúdos dos comentários se repetem e ofuscam o momento representado anteriormente.

O espaço real e o espaço virtual não se constituem como ambientes distintos quando o assunto é a sociabilidade humana. Comentários na postagem do tipo "Encontrei com vocês na orla!", "pq não chamou?", entre outros demostram que a dicotomia não existe, visto que as interações que iniciaram nos parques continuaram na rede, e o oposto também sucede de forma mútua.

Ainda que a memória não tenha centralidade na escrita em tela, importa também registrar as recorrências de clicks que resgatam fotos antigas de modo entrecruzado com as de hoje. É a promoção do futuro com a revelação no presente de imagens do passado. As lembranças da infância numa fotografia postada do filho, o resgate de uma pose durante a corrida realizada dois anos atrás e a retomada do passeio de bike da semana anterior têm o seu espaço garantido para rememoração de lembranças a partir das representações expostas nas superfícies fotográficas. 
A habitual volta à calma que costuma acontecer ao final da realização de uma corrida, um aulão de ginástica ou um passeio de bike parecem ter se reposicionado para o momento de reunião do grupo para fazer uma fotografia. O mesmo acontece com o aquecimento, que foi substituindo pela selfie da partida juntamente com o informe da programação do momento. A produção de imagens citadinas não é um fenômeno localista, está aqui, alí e lá. Está no parque, na praia, na casa, na sala. Não demore, seus seguidores estão ávidos pela sua próxima postagem. Se você seguir Djavan, saberá que "seus sinais me confundem da cabeça aos pés, mesmo assim eu te devoro". 6

\footnotetext{
Notas

${ }^{1} \mathrm{O}$ tempo de exposição é controlado através do obturador que é um dispositivo existente nos aparelhos fotográficos. O obturador, a sensibilidade da superfície em que a fotografia se forma e a abertura do diafragma constituem os elementos básicos da exposição fotográfica.

2 Simmel (1983, p. 169) a traduz sociologicamente como a "forma lúdica da sociação".

${ }^{3}$ Simmel (1983) caracteriza-os como superiores e inferiores, tendo a objetividade e a subjetividade, respectivamente, como os principais aspectos motivacionais da interação do indivíduo. Sendo assim, a discrição é fundamental para transitar entre estes limites, que não toleram o uso das qualificações objetivas dos papéis sociais do sujeito, nem de suas características puramente interiores e inteiramente subjetivas.

4 "Hashtag" é um termo utilizado em redes sociais com o objetivo de categorizar conteúdos, criando uma interação dinâmica entre os usuários. Expressa-se através de uma palavra que vem antecedida pelo símbolo \#, que no Brasil é popularmente conhecido como "jogo da velha".

${ }^{5} \mathrm{O}$ MAXQDA é um software que auxilia pesquisadores na análise qualitativa de dados e é fornecido pela empresa VERBI Software GmHB. Para este artigo, utilizamos o MAXQDA Analytics Pro 12, versão 12.3.2.

${ }^{6}$ Trecho da música "Te devoro", do cantor Djavan.
}

\section{Referências}

CASTEllS, Manuel; CARDOSO, Gustavo (Org.). A Sociedade em Rede: do conhecimento à ação política. Lisboa, PT: Imprensa Nacional, 2005. (Série Debates da Presidência).

CRESWELL, John W. Projeto de pesquisa: método qualitativo, quantitativo e misto. Porto Alegre: Artmed, 2007.

DEBORD, Guy. A Sociedade do espetáculo. Tradução: Estela dos Santos Abreu. 1. ed. Rio de Janeiro: Contraponto, 1997.

FEDOZZI, Luciano Joel; SOARES, Paulo Roberto Rodrigues; MAMARELLA, Rosetta. Dinâmica da metropolização brasileira: investigação da Região Metropolitana de Porto Alegre no período 1980-2010. In: FEDOZZI, Luciano Joel; SOARES, Paulo Roberto Rodrigues (Ed.). Porto Alegre: transformações na ordem urbana. (recurso digital). 1. ed. Rio de Janeiro: Letra Capital; Observatório das Metrópoles, 2015. p. 17-41.

FRAGOSO, Suely; RECUERO, Raquel; AMARAL, Adriana. Métodos de pesquisa para internet. Porto Alegre: Sulina, 2011.

JOLY, Martine. Introdução à análise da Imagem. Tradução:José Eduardo Rodil. Lisboa, PT: Edições 70, 2007. 
LAZZAROTTI FILHO, Ari. et al. O termo práticas corporais na literatura científica brasileira e sua repercussão no campo da Educação Física. Revista Movimento, Porto Alegre, v. 12, n. 1, p. 11-29, jan./mar. 2010.

LEIRO, Augusto Cesar Rios. Lazer e educação nos parques públicos de Salvador: encontro de sujeitos em espaços de cidadania. 2001. Dissertação (Mestrado em Educação) - Faculdade de Educação, Universidade Federal da Bahia, Salvador, 2001.

PLATÃO. A República. São Paulo: Martin Claret, 2002.

SANTOS, Tania Steren. Do artesanato intelectual ao contexto virtual: ferramentas metodológicas para a pesquisa social. Sociologias, Porto Alegre, v. 11, n. 22, p. 120-159, dez. 2009. Disponível em: https://bit.ly/2KKD8kU Acesso em: 29 out. 2017.

SIBILIA, Paula. O show do eu: a intimitade como espetáculo. Rio de Janeiro: Nova Fronteira, 2008.

SIMMEL, Georg. Sociologia. São Paulo: Ed. 34, 1983. 